\title{
薄膜材料を対象とするオンチップ引張疲労試験 システムの開発*
}

\author{
安藤妙子** 吉岡テッ $7^{* * *}$ 式田光宏 ${ }^{\dagger}$ 佐藤一雄 $^{\dagger \dagger}$ \\ Development of Fatigue Testing System Based on On-chip Tensile Test for Thin Film Material \\ Taeko ANDO, Tetsuo YOSHIOKA, Mitsuhiro SHIKIDA and Kazuo SATO
}

\begin{abstract}
Fatigue test of single-crystal-silicon thin films under uniaxial tensile condition was performed on a silicon chip. In this on-chip tensile testing method, tensile testing specimen integrated with loading mechanisms on a same silicon chip was used for the characterization of mechanical property.A newly introduced testing machine allowed experiments under both quasi-static and dynamic loading conditions. An external loading actuator pushing the testing chip precisely traveled in horizontal direction owing to air bearing support and linear DC servomotor. The displacement of the actuator was detected with a sensor having a resolution of $0.1 \mu \mathrm{m}$, and applied load was measured by a load cell with a resolution of $1 \mathrm{mN}$. Measurement accuracy was proved by performing quasi-static tensile test of single-crystal-silicon whose tensile axis was oriented in a $<100>$ direction. Sinusoidal cyclic load was applied to the testing chip with the maximum strain of $3.9 \%$ and the frequency of $10 \mathrm{~Hz}$. Fatigue failure was observed as a decrease in the detected force, while the applied displacement didn't change.
\end{abstract}

Key words: fatigue test, single crystal silicon, thin film, micromachine, uniaxial tensile test, quasi-static condition, dynamic condition

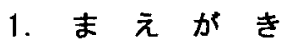

マイクロマシンは基礎研究の段階から製品開発の段階を迎え, センサ, 計測機器, 情報機器などの分野で新しいデバイスが 次々に実現している。一方で, マイクロマシンの機能や構造の 信頼性を確保するために重要な, 構成材料の機械的特性を把握 することは，立ち遅れている。ママイクロマシンの作製には，半 導体集積回路の加工プロセス技術を応用展開した, マイクロマ シニング技術が使われている。 その結果, シリコンやシリコン 化合物の薄膜，金属膜など，これまで機械的用途に使われたこ とのない材料に，機械的な役割が求められるようになった。バ ルク材料の機械的性質は寸でに研究され，その值嵖らかに なっているが，薄膜材の性質はバルク材のものとは異なる。さ らに同じ構成の材料でも，機械的性質はプロセス条件に传存し て大きく変化する．また膜幥が非常に薄いものになった場合， 膜厚による寸法効果が生じるといわれている. したがって使用 する薄膜材に対して改めて機械的性質を計測する必要があるが， 薄膜材の機械的特性を評価する手法が確立されておらず，デバ イス製作者自らが，使用寸る材料の特性を独自の方法で評価し ているのが現状である。

薄膜の機械的特性評価の目的で, これまで引張試験, 曲げ試 験，バルジ試驗，インデンテーシション試験など様々な手法が微 細な試験材料に対して適用されている，その結果，弾性係数， 内部応力，破断強度など，デバイスの機能を決定づける重要な パラメータが，徐々に明らかにされつつ女る，様々な試験法の 中で, 引張試験は試験片に均一応力場を加えることができ, † ング率や応力・ひずみを最も直接的に測定することができる手

* 原稿受付平成 12 年 4 月 20 日

** 学生会員 名古屋大学大学院 (名古屋市干種区不老町)

*** 名古屋大学大学院 (現, (柇)デンシー：日進市米野木町南山 500-1)

†名古屋大学大学院

计正会員 名古屋大学大学院
法である，しかし試験片の把持，操作が難しいことから，薄膜 材料には適用されることが少なかった，筆者らは，薄膜試験片 を負荷機構と共にシリコンデバイス上に形成し，薄膜を基板か ら分離することなく引張試験を実施できる「オンチップ引張試 験法」を提案し，これを単結晶シリコン，シリコン酸化膜, 窒 化膜に適用して、ナング率と破断ひずみを測定してきた ${ }^{1) ~ 3 ! . こ ~}$ のような準静的な試験によって得られる材料の機械的性質上な らんで,繰返し応力によって生じる材料の破壊に対する評価は， デバイスの寿命の予測に際して久くことができない，すでに， マイクロ材料として最も一般的な材料の一つである单結晶シリ コンに関して，大気中や高湿度環境中で、動疲労による破壊が

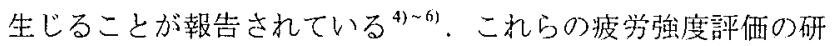
究では, マイクロマシンデバイス自体に外力を加えて其振させ る方法や，3点曲げあるいは片持ちはり曲げなどの曲げ試験法 が適用されている。引張試験による疲労強度の調查注, 金属薄 膜に関して疲労強度を評価した報告もあるが，その数はまだ少 ない, ${ }^{7-8)}$.

本研究ではオンチップ引張試験法の原理に基づき, 薄膜材に 超低速度で荷重を加えたり，あるい性繰返し荷重を加えたりす ることのできる、新しい試験システムを導入した。この試験装 置を用い，十分な精度をもって準静的・動的試験を実施できる ことを確認した．本論文ではオンチップ引張試験法の原理と新 しく開発したオンチップ引張疲労試験システムについて述心゙, 実際に単結晶シリコン薄膜を対象として実施した引張試験, 疲 労試験の結果を報告する。

\section{2. 実 験 方 法}

\section{1 オンチップ引張試験法}

オンチップ引張試験法は，マイクロ材料を対象とした機械的 特性の評価法である.試験チップの基本構造を図!に示す、チッ プはマイクロ試験片が，負荷機構を構成するトーションバー， 


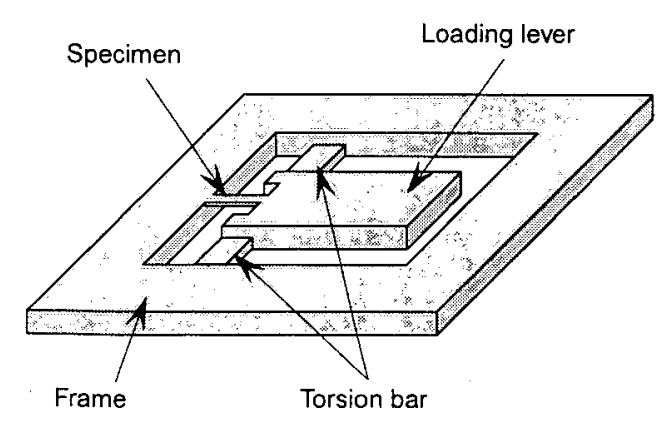

Fig. 1 Testing chip structure of on-chip tensile testing method

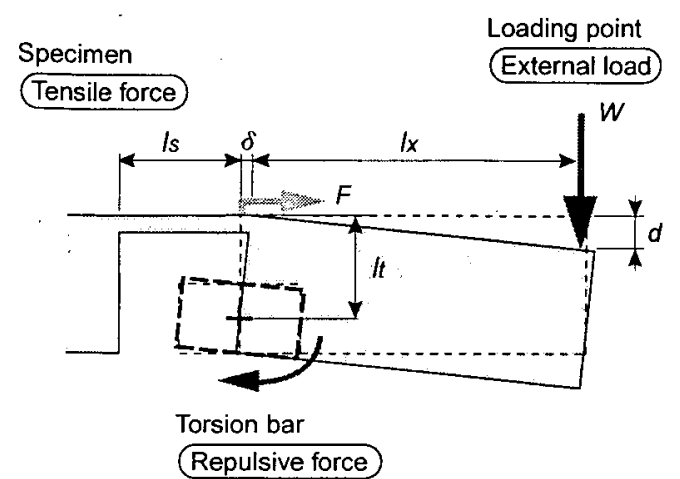

(a)

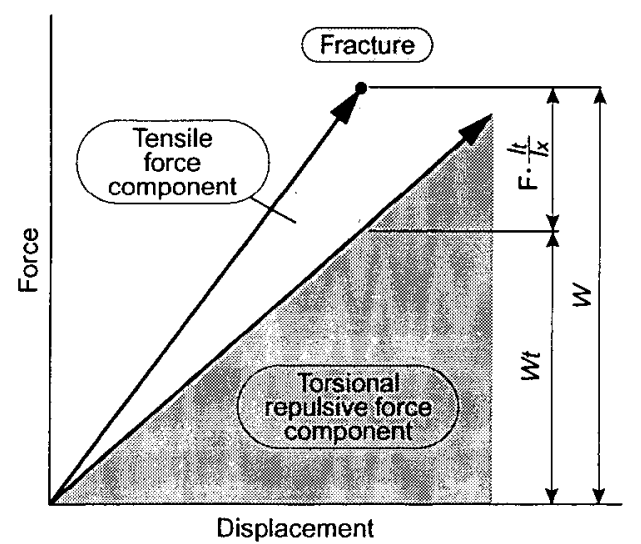

(b)

Fig. 2 Principle of on-chip tensile test: (a) Cross-section of testing device under loading; (b) Schematic view of the relationship between force and displacement at loading point

レバー, フレームと一体に形成されている.

チップ中心部の断面図を図 2 (a)に示す。試験片は，フレー ムとロードレバーの間にブリッジ状に支持され，それぞれの端 点で固定されている．図のように，レバーの先端を上方から垂 直下向きに押したとき，レバーはトーションバーの軸を中心に して回転し，レバーと一体となった試験片は，図の右方向へと 引っ張られる、レバーの回転角が十分に小さいとき, 試験片に 加えられた力は単軸引張力と近似できるため, マイクロ材料の 引張試験が実現できる.

オンチップ引張試験の特徵は二つある.一つは, 試験片と試 験片に引張力を加えるための負荷機構が，一つのチップ上で一 体になっていることである、このため, 実験時のハンドリング で試験片にダメージを与えるおろれがない．そして二つめは， 次節で述べるように，試験片の伸びをレバーの変位に比例拡大 して計测することである. したがって，材料が微小であり，さ

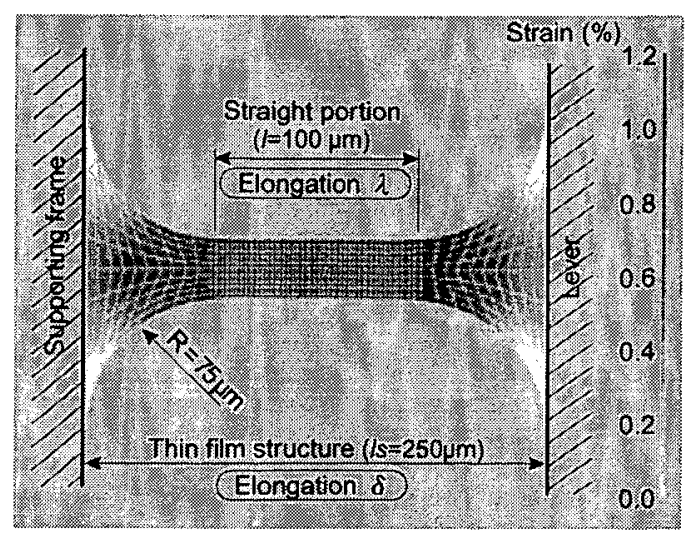

Fig. 3 FEM analyzing result of strain distribution in film specimen structure

らに伸びひずみ量が小さい刘象物であっても，伸びの評価が容 易になる. 以上の二つの特徴から本試験法は、マイクロマシン 材料では最も一般的な, シリコンやシリコン化合物などのぜい 性材料の薄膜を対象とするとき，非常に適した手法である。

\section{2 弾性係数、破断応力の解析}

本節では, オンチップ引張試験における諸物性值の解析法に ついて述べる。

図 2 (a)のように, ロードレバー上の一点に, 外力 $W$ が鉛直 下向きに加えられている場合を考える，このとき，試験片には ロードレバーとの接点に右向きの力, またトーションバーには 回転中心に時計回りのモーメント力が働く、荷重点の鉛直下向 きの変位と，これらの力との関係を表した模式図を図 2 (b)に 示す. 荷重点における鉛直下向きの外力は, 試験片を引つ張る 力とトーションバーをねじる力の 2 つの成分から成り立つ.こ れら3つの力の，トーションバーの回転中心まわりにおける モーメントの釣合い式は式(1)で表される.

$$
W l_{x}=F l_{t}+W l_{x}
$$

ここで, $W$ は荷重点を押し下げる力, $W$ は荷重点でのトーショ ンバーのねじり反力に相当する力， $F$ はレバーと試験片の接点

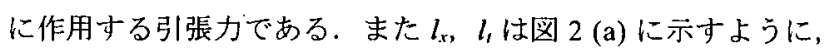
試験片の端点からそれぞれ荷重点, トーションバーの回転中心 までの距䧺である。トーションバーのねじり反力成分 $W$ 岋式 (1)吕ら明らかなように, 試験片の破断後に変位一荷重関係を測 定することにより独立に評価できる.したがって, 試験片の破 断前後の荷重を測定することによって, 試験片の引張力が求め られ，応力を式 (2)のように計算することができる.

$$
\sigma=\frac{F}{A}=\frac{l_{x}}{A l_{t}}\left(W-W_{t}\right)
$$

ここで $A$ は試験片の断面積である.

試験片端点の変位 $\delta$ は, ロードレバーの回転角と回転中心ま での距離しから求めることができる。ここで一般に，荷重点の 距離 $\left(l_{x}=7 \mathrm{~mm}\right)$ に対して荷重点の変位 $(d=50 \sim 200 \mu \mathrm{m})$ は非常に 小さいため，ロードレバーの回転角は十分小さく，以下の近似 式が成り立?.

$$
\delta=\frac{l_{t}}{l_{x}} d
$$

すなわち, 試験片端点の変位は, 荷重点の距離と回転中心の距 離の比例則から求めることができ，また変位が微小であっても それを桩大険出することができる.

フレームとレバーの間に固定されている薄膜試験片の形状は, 平行部とその両端に忍力集中緩和用の円弧がついたものである 


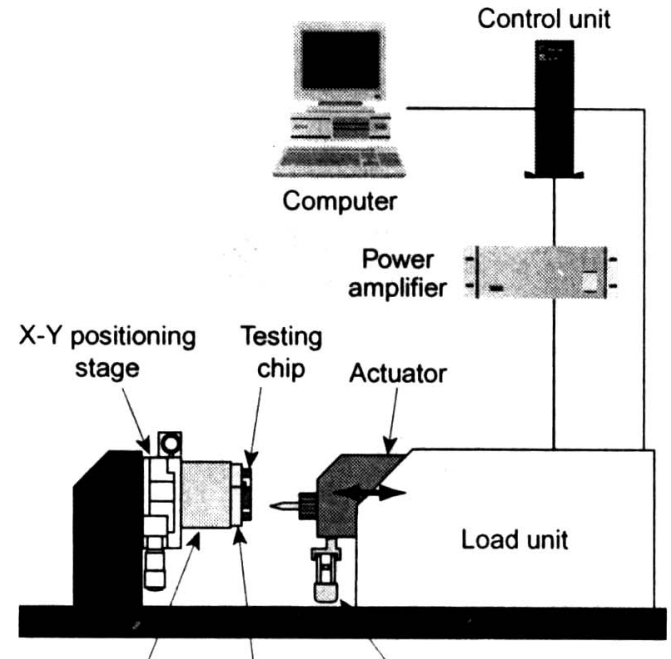

Load cell Vacuum stage Displacement gage

Fig. 4 Testing system newly introduced for measuring smaller displacement and force on quai-static and dynamic loading condition

Table 1 Specification of Tytron 250

\begin{tabular}{lll}
\hline Actuator & $\begin{array}{l}\text { type } \\
\text { speed }\end{array}$ & $\begin{array}{l}\text { linear DC servo } \\
\max .0 .5 \mathrm{~m} / \mathrm{s}\end{array}$ \\
& $\begin{array}{l}\min 1 \mu \mathrm{m} / \mathrm{h} \\
\max .50 \mathrm{~Hz}\end{array}$ \\
\hline $\begin{array}{l}\text { Displacement } \\
\text { (high-resolution }\end{array}$ & $\begin{array}{l}\text { range } \\
\text { disp. gage) } \\
\text { range }\end{array}$ & $\pm 50 \mathrm{~mm}$ \\
& resolution & $\pm 2 \mathrm{~mm}$ \\
\hline Load & range & $\pm 1 \mu \mathrm{m}$ \\
& resolution & $1 \mathrm{mN}$ \\
\hline
\end{tabular}

(図 3).このため, 平行部の両側にある薄膜構造の全体のひず み分布がわからなければ, 中央の平行部に加わる伸びひずみを 評価できない，薄膜構造全体のひずみは, FEMによって解析し た. 図 3 はFEM で解析したひずみ分布の一例である. 試験片 平行部の伸び $\lambda$ と, 全体の伸び $\delta$ の比 $a(=\lambda \delta)$ は, 平行部の長 さが $50 \mu \mathrm{m}$ のときにおよそ $0.3,100 \mu \mathrm{m}$ のときおよそ 0.45 で あった. したがって, 試験片平行部のひずみは,この係数を使っ て次式で評価した。

$$
\varepsilon=\frac{\lambda}{l}=\frac{\delta a}{l}=\frac{l_{l} a}{l_{x} l} d
$$

lは, 試験片平行部の長さである.

以上のように応力とひずみが得られたので, 式 (2), (4) よりヤ ング率 $E$ は次式で与えられる.

$$
E=\frac{\sigma}{\varepsilon}=\frac{l_{x}^{2} l}{A l_{t}^{2} a} \times \frac{W-W_{t}}{d}
$$

右辺第 2 項より, 荷重点における変位と荷重の関係, 寸なわち 図 2 (b) のグラフが得られれば, その直線の傾きからヤング率 を求めることができる.

\section{3 疲労試硂システム}

試験には MTS 社製 Tytron ${ }^{\mathrm{TM}} 250$ 微小荷重用試験機を導入し た。本試験装置では準静的，または動的に微小荷重を加えるこ とができる、装置の概略図を図 4 に示す。本装置は, 試験機, 制御装置, パワーアンプ, コンピュータで構成されている。試 験機本体内のアクチュエータはエアベアリングで支持され，リ ニア DCサーボモータを用いた閉ループ制御によって, 水平方 向に高精度な動作が得られる.アクチュエータの変位はリニア

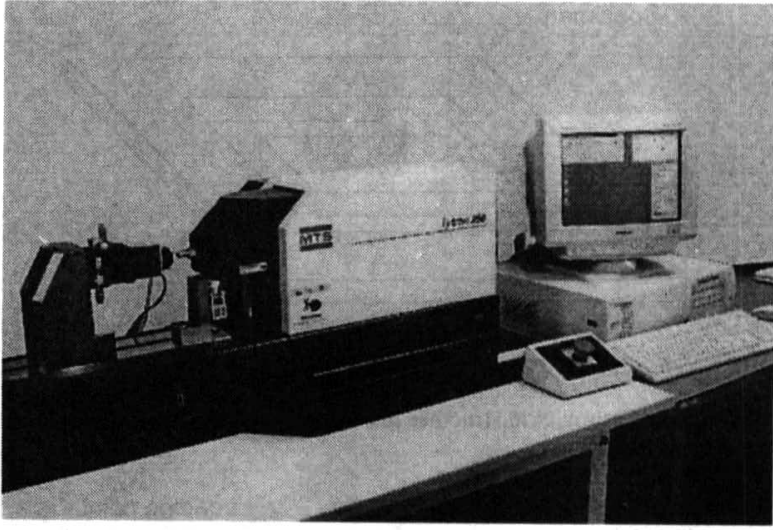

(a)

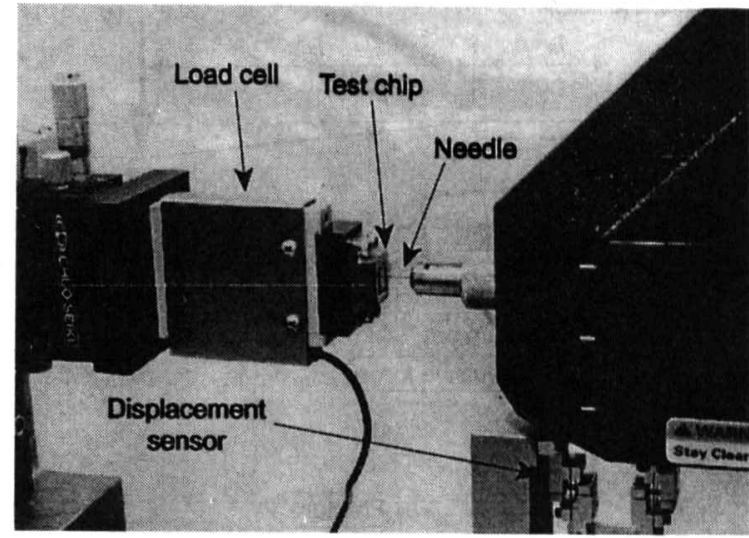

(b)

Fig. 5 Photograph of the on-chip fatigue test system: (a) overall view; (b) experimental setup

モータからのフィードバック信号から検出する一方, 荷重の検 出はロードセルによって行う。しかし，さらに高精度な変位の 検出が必要であるため, ひずみゲージ式の高分解能変位計 (分 解能 : $0.1 \mu \mathrm{m})$ をアクチュエータに取り付け，コントロールユ ニットに組み込んだ．変位計，ロードセルを含めた本試験装置 の仕様を表 1 に示寸. パーソナルコンピュータ上ではアクチュ エータの制御を行うとともに, 変位や荷重の情報をリアルタイ ムで表示し, データの処理を行う。入力信号は直線的な負荷の 他, 三角波・矩形波・正弦波のような形状から選択でき, これ らによる繰返し負荷が可能である，本研究では, 変位を制御す る試験方式を採用した. 今回疲労試験では, 引張応力下で正弦 波状の繰返し荷重を加え, 試験片が破断するかあるいは試験片 に $10^{6}$ サイクル負荷した後, 除荷するように設定した。変位制 御で測定を行うため, 試験片の破断は荷重の変化で検知できる. したがって,荷重の急激な変化に対してトリガを設定しておき, 試験片の破断を検出した.

測定システム全体の写真を図 5 (a) に示寸。この試験システ ムでは, (1) 試験チップをステージ上に正確に固定すること,(2) ロードレバー上の定めた位置に荷重を加えること, が重要であ る. 試験の手順は以下の通りである. まず, 試験チップと真空 ステージの位置合わせを試験機外部の顕微鏡の下で行い, 真空 吸着によって試験チップをステージに固定する. チップを吸着 したままの真空ステージを試験機上に移動し，ロードセルの端 面に鉛直縦置きにして取り付け, 試験チップがアクチュエータ と正対するようにセットする. 真空吸着は十分に強く, 試験中 にチップが移動することはない. 一方, アクチュエータの先端 に取り付けた負荷用のステンレス製の針の先端とチップとの位 


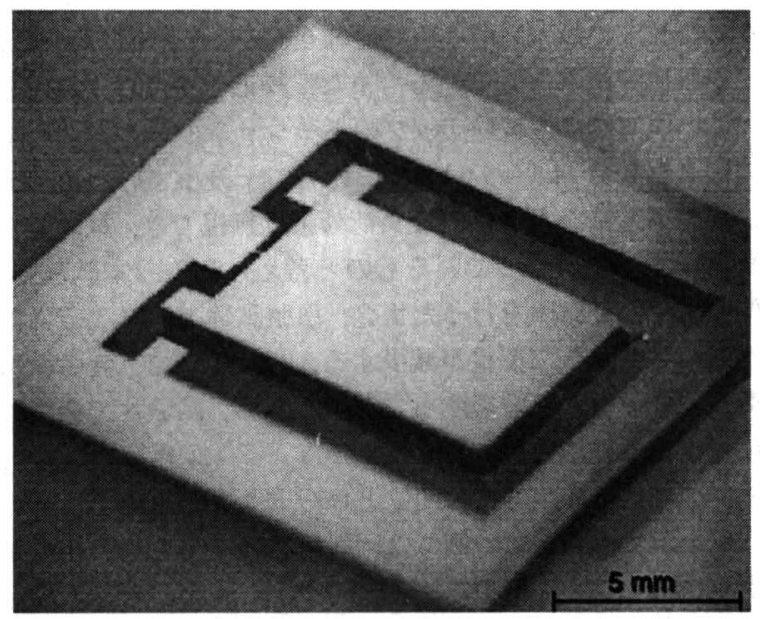

(a)

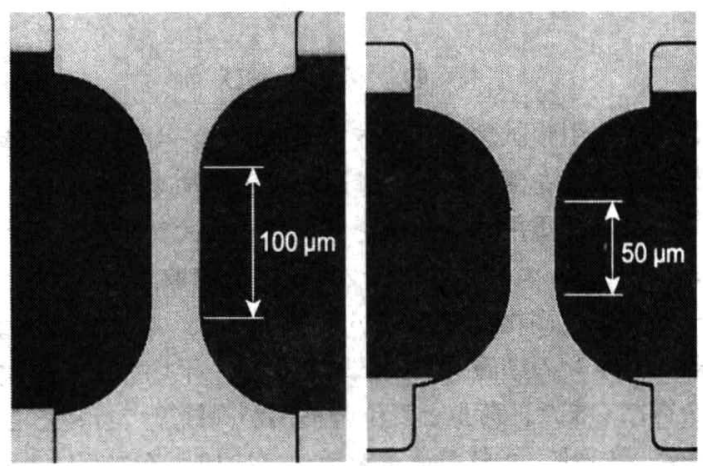

(b)

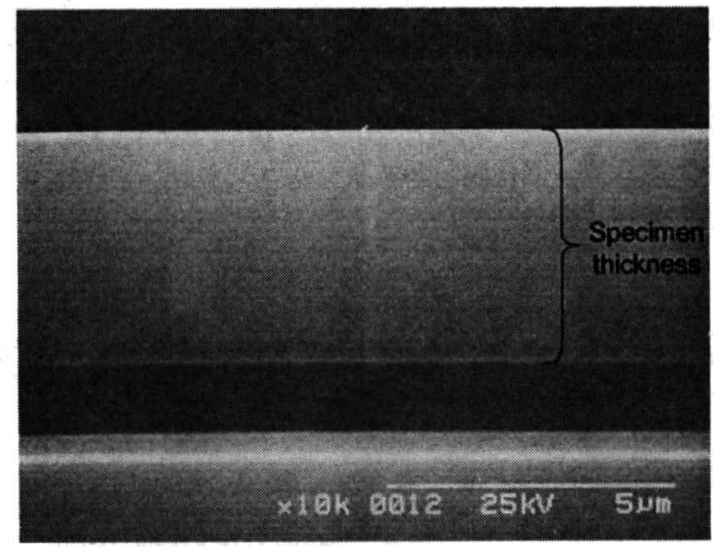

(c)

Fig. 6 Photograph of testing device: (a) overall view of testing chip with single-crystal-silicon specimen; (b) magnified views of the specimen (c) SEM photograph of the specimen side

置合わせは，ロードセル側の XY ステージで行う。実験を開始 すると,アクチュエータはゆっくりとチップ側へと移動し，ア クチュエータ上の針がレバーに接触した時点から，測定を開始 する. 実験中の負荷部分の拡大写真を図 5 (b) に示した. 中央に 試験チップとレバーを押している針がある. 高分解能変位計は アクチュエータの下に取り付けられており，また，ロードセル は写真左の XY ステージ端面に固定されている.

\section{3. 試 酫 結 果}

\section{1 試験チップ}

作製した試験チップおよび試験片の写真を図 6 に示す。本試 験では, 試験材料として面方位が (100), 引張方位が < 100>0)

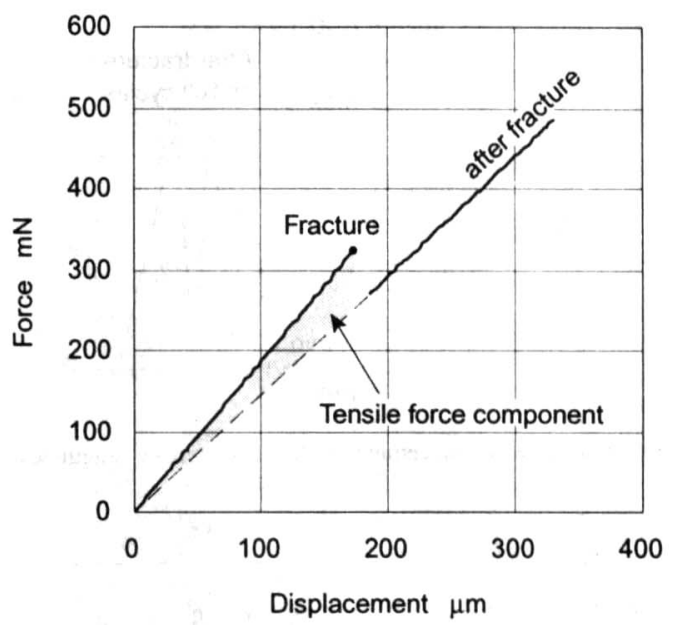

Fig. 7 Relationship between the detected force and the displacement on the loading lever end during quasi-static loading for single-crystal-silicon specimen having $<100>$ orientation

単結晶シリコンを用いた. 試験チップの作製方法は既報”にて詳 述した．試験片部分の作製方法は以下のとおりである。試験片 を構成する表層のシリコンと, トーションバーやレバーなどの 負荷機構を構成するシリコンは, それぞれ別の (100) シリコン 基板からなる. 2 枚の (100) 基板を面内に回転させて, それぞれ 試験片，負荷機構として適切な方位に位置合わせしたのち，シ リコン酸化膜を介して貼り合わせて SOI (Silicon on Insulator) 基 板とし、これを試験チップの素材とした．試験片表面は通常の シリコンウェハの鏡面研磨仕上げの状態とし，試験片の輪郭は $\mathrm{SF}_{6}$ ガスを用いた反応性イオンエッチングで加工した. また試験 片の裏面は，基板裏面から TMAH (Tetra Methyl Ammonium Hydroxide) 水溶液による結晶異方性エッチングによって, 貼り合わ せ酸化膜まで基板を除去したのち，残った酸化膜をフッ酸と フッ化アンモニウムの 1:6 混合液でエッチング除去した。試験 チップの寸法は $15 \mathrm{~mm} \times 15 \mathrm{~mm} \times 0.5 \mathrm{~mm}$ (図6(a)) である.レバー の厚さが $0.5 \mathrm{~mm}$ であるのに対してレバーの長さは $7 \mathrm{~mm}$ である ため, 試験片の伸びはおよそ 15 倍に拡大して荷重点の変位とし て検出できる、トーションバーの厚さは，100 200 $\mu \mathrm{m}$ である. 図 6 (b) に試験片の拡大写真を示寸. 試験片の平行部の寸法は以 下の通りである.

$$
\begin{array}{lc}
\text { 長さ } & 100 \mu \mathrm{m}, 50 \mu \mathrm{m} \\
\text { 幅 } & 40 \mu \mathrm{m} \\
\text { 厚さ } & 5 \mu \mathrm{m}
\end{array}
$$

試験片側面は, 図 6 (c) に示すように非常に滑らかで, エッチン グによる粗面化は極めて抑制されている.

\section{2 準静的引張試験}

前述した試験装置を用い, 単結晶シリコン $<100>$ 方位に対し てオンチップ引張試験を実施した. 図 7 に長さ $50 \mu \mathrm{m}$ の試験片を 用いて, 準静的負荷による引張試験を実施したときの, 荷重点 における荷重と変位の関係の一例を示す. 試験は変位制御にて 行われ, 最初に一定速度でレバー上の一点を押し込む. 荷重が 急激に低下したときにトリガがかけられ, その後さらに一定量 の変位が与えられる.グラフ上の荷重一変位曲線がいったんとぎ れた点が試験片が破断した点であり, その後もレバーに変位を 与えることで, トーションバーに加わるねじり力と変位の関係 を調べることができる. 今回の測定では, 荷重点における押込 み速度は $5 \mu \mathrm{m} / \mathrm{s}$, 試験片のひずみ速度は $0.002 \mathrm{l} / \mathrm{s}$ とした. 単結 


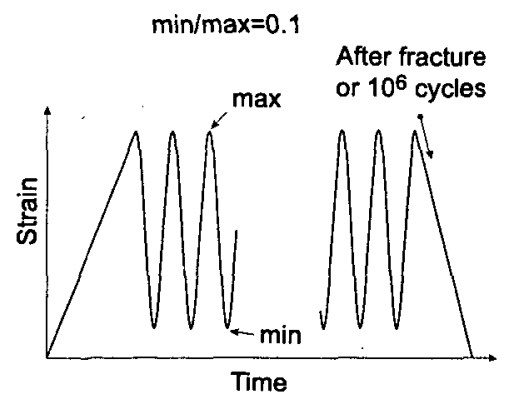

Fig. 8 Applied displacement mode during tensile fatigue test

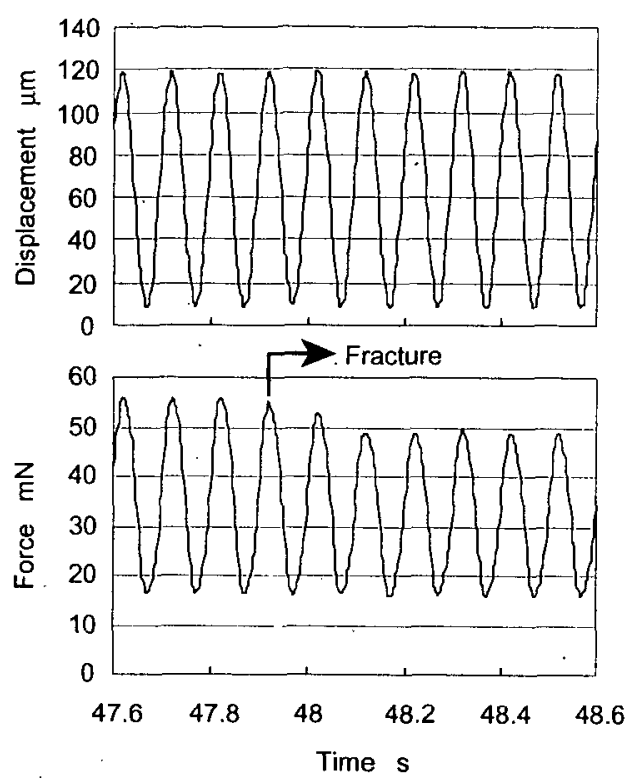

Fig. 9 The variation of displacement of the lever and detected force before and after fracture

晶シリコンの試験では荷重と変位は直線関係を示すが，グラフ より十分な精度をもって荷重と変位の測定を行えることが保証 できる.

今回行った試験数は 10 で，試験片の長さが $50 \mu \mathrm{m}, 100 \mu \mathrm{m}$ の試験片を，それぞれ 4，6サンプルずつ測定した。式 (5) を 使って求めたヤング率の平均值は $119 \mathrm{GPa}$ で，筆者らが過去に 報告した試験結果 ${ }^{12)}$ と変わらない值が得られた。一方破断ひず みの平均值は $3.6 \%$ で, 破断応力は $4.3 \mathrm{GPa}$ であった. 筆者らの 以前の実験では，平行部の長さが $400 \mu \mathrm{m}$ の試験片を用いてお り，2\%以上のひずみを得た場合，試験片が破断する前にトー ションバーが大きなねじれ変形を受けて破壊していた，本試験 では試験片の長さを短くしたことにより，トーションバーのね じれ変形が小さくても試験片に十分大きなひずみが加わり，破 墑応力を評価することができた。

\section{3 度労試}

本試験機を使って，試験片の波労強度を調べるためにチップ に繰り返し荷重を加え, 動疲労試験を行った，対象材料は準静 的引張試験と同様に, 引張方向が $<100>$ 方位の単結晶シリコン である. 図 8 に, 疲労試験におけるひずみの変化を示す.最初 は準静的引張試験と同様，一定速度で増加していき，設定した 最大ひずみに達したところで正弦波状の増減に変化する。この
ときの正弦波の最大/最小值の比は 0.1 となるように設定し、引 張一引張疲労試験としている。 また, 繰返し速度は $10 \mathrm{~Hz}$ とし た.この周波数は，試験チップのトーションバーのねじれモー ドの固有振動数 $(4.5 \sim 5.0 \mathrm{kHz})$ に比べて十分小さいため, 試験 チップの構造亲がもつ動的な負荷効果は無視でき，試験機によ る負荷がすべて伝わっているものと考えられる．本試験では， 変位制御により試験を行った場合, 引張試験と同じように試験 片が破断したときに荷重が減少寸る。したがって，疲労試験で は荷重の変化を常時監視することによって, 試験片の疲労およ び疲労による破壊を検知できる。

図 9 にアクチュエータの変位とロードセルから出力された荷 重の例を示す。グラフの例では，引張試験で得られた平均破断 ひずみに対して 1.1 倍のひずみ $(3.9 \%)$ を最大ひずみと設定し た。その結果, この試験片は383 回の繰返し荷重によって壊れ た.

\section{4.むすひ}

オンチップ引張試験法を使って薄膜材料を引張疲労試験する ための測定装置を開発した。䆆返し荷重を加えるために，水平 駆動式の微小荷重用の試験機を導入した。試験装置本体内のア クチュエータは,エアベアリングによる低摩擦，リニア DCサー ボモータによる高精度な駆動が可能である。本試験機により， 単結晶シリコンの準静的引張試験を行い，平均 $3.6 \%$ の破断ひ ずみを得た，また，荷重と変位の検出が高精度で行えることを 確かめた.さらに, 正弦波荷重をチップに加えることにより, 疲 労試験を実施した，変位制御による疲労試験では，試験中の疲 労破壊を荷重の変化によって観察できることを確認した，今後， さらに単結晶シリコンの引張疲労試験を行い，単結晶シリコン の疲労破壊のメカニズムの解明に取り組む予定である。また， シリコン酸化膜, 坴化膜, 多結晶シリコン薄膜へと試験材料を 拡張する予定である。

\section{躴辞}

本研究は, 文部省科学研究費補助金基礎研究 (A) (2) 10305008 のもとで進められた。ここに記して謝意を表する。

\section{参 考 文 献}

1) K. Sato, T. Yoshioka, T. Ando, M. Shikida and T. Kawabata: Tensile Testing of Silicon Film Having Different Crystallographic Orientations Carried out on a Silicon Chip, Sensors and Actuators, A 70, (1998)148.

2) 安藤妙子, 吉岡テッラ, 式田光宏, 佐藤一雄, 川畑達央: オンチップ 引張試験によるシリコン薄膜の応力とひずみの测定, 電気学会論女誌 E, 119-E, 2, (1999) 67.

3) T. Yoshioka, T. Ando, M. Shikida and K. Sato: Tensile Testing of $\mathrm{SiO}_{2}$ and $\mathrm{Si}_{3} \mathrm{~N}_{4}$ Films Carried out on a Silicon Chip, Tech. Digests of Transducers '99, 1, (1999) 496.

4) 駒井謙治郎, 箕島弘二, 井上茂道, 藤井秀敏: Si 単結晶マイクロエレ メントの破壊・疲労特性評価と水環境効果, 日本機械学会論文集A, 62, $596,(1996) 88$.

5) T. Tsuchiya, A. Inoue, J. Sakata, M. Hashimoto, A. Yokoyama and M. Sugimoto: Fatigue Test of Single Crystal Silicon Resonator, Tech. Digests of 16th Sensor Symp., (1998) 277.

6) 後藤博史, 池田正哲, 坂田 稳, 今仲行一: 小型 2 次元光走查機構の開 発（第 2 報, 低電厓駆動，大走查角化を目的とする 2 自由度板ば权振 動子の高性能化)，日本機械学会諭文集 C, 62, 600 (1996) 262.

7) D. T. Read and J. W. Dally: Fatigue of Microlithographically-patterned Freestanding Aluminum Thin Film under Axial Stresses, J. Electron. Packaging, $117,(1995) 1$.

8) D. T. Read: Tension-tension Fatigue of Copper Thin Films, Int. J. Fatigue, 20, 3, (1998) 203. 